\title{
Die betekenis van kerkgeskiedenis vir vandag
}

\author{
S J Botha \\ Departement Kerkgeskiedenis (Afd A) \\ Universiteit van Pretoria
}

\begin{abstract}
The meaning of Church history today

The topic is discussed on the basis of three questions: What is Church history? Does Church history have any meaning? and, Is it really necessary for the present generation to communicate with the past?
\end{abstract}

\section{INLEIDING}

Veertig jaar gelede het prof A D Pont die leerstoel Geskiedenis van die Christendom aan die Fakulfeit Teologie Afdeling A van die Universiteit van Pretoria aanvaar. In die preek of intreerede wat hy op 17 Maart 1957 gehou het, wat die titel Die Geskiedenis van die Christendom (Pont 1957:2-8) gedra het, het hy kortliks gehandel oor die rigting en taak van hierdie bepaalde onderdeel van die teologiese wetenskap. Hy het dit gedoen in die voetspoor van twee Bybeltekste naamlik 1 Korinthiërs 10:11 en Hebreërs 9: 26b. In sy rede het hy onder andere ook gehandel oor die betekenis van die verlede in die hede, of anders gestel, die betekenis van die geskiedenis vir vandag. Juis op grond van die teks uit die Korintiërbrief, was sy slotsom:

Die verlede verswaar die verantwoordelikheid van die hede. Die betrekking van die verlede in die hede beteken die inskerping van sy verantwoordelikheid vir die geslag van vandag wat die toekoms nog voor hom het. Omdat daar 'n verband bestaan tussen die verlede en die hede, daarom dra die hede 'n swaarder verantwoordelikheid teenoor die toekoms.

(Pont 1957:4)

Dat die intreerede van veertig jaar gelede by hierdie geleentheid in herinnering geroep word, en soos die opskrif van hierdie voordrag duidelik na vore bring, dat in besonder na die bepaalde aspek van die betekenis van die geskiedenis vir vandag gekyk moet word, het ten doel om hulde te bring aan professor Pont wat binnekort, op 21 September vanjaar, sy sewentigste verjaardag sal vier, se bydrae om die kerkgeskiedenis vir 
die kerk van vandag lewend te hou. Hoewel reeds byna vyf jaar sedert sy aftrede verloop het, is hy steeds aktief op sy vakgebied besig en lewer hy ook nog gewaardeerde doseerhulp in dieselfde departement waarvan hy vir ses-en-dertig jaar hoof was. Vir meer as sy geroepe dienstyd het hy met nougesetheid en toewyding die kerkgeskiedenis as werklikheid nagevors en beskryf en sodoende voortdurend gepoog om 'n lewende verhouding tot stand te bring tussen die Nederduitsch Hervormde Kerk van vandag en sy geskiedenis (Botha 1980:5).

Om opnuut oor die aspek van die betekenis van kerkgeskiedenis vandag te besin, bied die geleentheid om dit ook weer onder aandag van die Nederduitsch Hervormde Kerk te bring dat die Bybelse opvatting oor die waarde van die geskiedenis dit noodsaaklik maak dat die gebeurtenisse van gister geken moet word. Dit kan alleen tot nadeel van die Kerk wees, wat vandag 'n verantwoordelikheid ten opsigte van môre het, om die geskiedenis en die bestudering van die geskiedenis te verwaarloos (Pont 1991).

Om oor die onderwerp soos geformuleer te handel, sal aan elkeen van die samestellende komponente aandag gegee word. Eerstens sal oorweeg word wat kerkgeskiedenis is, daarna kom die vraag aan die orde of (kerk)geskiedenis wel betekenis het en laastens word gevra of dit noodsaaklik is vir die hede om met die verlede in gesprek te tree.

\section{2. (KERK)GESKIEDENIS}

Dit lyk byna onnodig om die vraag aan die orde te stel wat geskiedenis of dan in die geval wat kerkgekiedenis is. Die wyse waarop die meeste mense die woord geskiedenis gebruik, skep die indruk dat hulle wel deeglik weet wat geskiedenis is (Van Jaarsveld 1959:1). Die oomblik egter as daar gevra word na 'n algemeen aanvaarbare definisie van (kerk)geskiedenis, dan blyk dit nie so 'n eenvoudige saak te wees nie. Dit het 'n ervare historikus al van geskiedenis laat sê:

$\mathrm{Na}$ byna tweeduisend jaar Westerse ervaring met geskiedskrywing - en die is 'n tipiese Westerse geestesproduk - is die historici nog nie in staat om 'n uitputtende en algemeen aanvaarbare definisie van geskiedenis te gee nie: dit is blykbaar net so ondefinieerbaar, onuitputlik en ingewikkeld soos die lewe self, waaruit die geskiedenis voortkom.

(Van Jaarsveld 1976:1) 
As dit van geskiedenis geld, dan moet van kerkgeskiedenis erken word dat hierin in die loop van die eeue ook geen algemene eenstemmigheid onder kerkhistorici gevind word nie (Berkhof 1950:8). 'n Kort ekskurs in die gekiedenis van kerkgeskiedskrywing toon dit duidelik (vgl Pont s a:5-35). Afgesien daarvan dat kerkhistorici onderling verskil oor wat geskiedenis is, is daar ook geen algemene eenstemmigheid oor die begrip kerk nie. Noodwendig moet die kerkhistorikus hom verantwoord oor wat kerk is, omdat dit vir hom die inhoud en die omvang van sy studieveld aandui. Selge stel die saak so: 'Gegenstand der Kirchengeschichte ist die christliche Kirche. Einfach genug, so mag es scheinen. Aber was ist die christliche Kirche - als Gegenstand der Kirchengeschichte betrachtet' (Selge 1982:1)?

Die Rooms-katolieke kerkhistorikus Hubert Jedin kan gelyk gegee word as hy beweer: 'Vom Begriff der Kirche hängen Verständnis und Sinngebung der Kirchengeschichte ab' (Jedin 1963:3).

Dit is seker voor die handliggend dat daar radikale verskille tussen Protestantse en Rooms-katolieke kerkhistorici sal wees. Selfs in die geledere van die Protestante vind mens egter nie die verwagte eenstemmigheid nie. Trouens die drie Afrikaanse kerke is 'n voorbeeld waar die kerkbegrip eendersluidend in die gemeenskaplike belydenisskrifte geformuleer is en waar, teoreties gesproke, die teologiese gesigspunt dieselfde behoort te wees, maar waar daar tog nog ernstige en diepgaande verskille bestaan oor die interpretasie van bepaalde aspekte van die gemeenskaplike verlede (Pont 1963:146-153).

Om nou terug te keer tot die vraag wat geskiedenis is, kan enkele opmerkings oor die betekenis van die woord geskiedenis nuttig wees. Afgelei van 'n Duitse woord gaan dit om iets wat gebeur het en wat in die verlede lê. Daar word egter ook 'n tweede betekenis aan die woord geskiedenis geheg omdat die verhaal van wat gebeur het, ook met dié woord aangedui word (Van Jaarsveld 1977:1). Sonder om verder in besonderhede daarop in te gaan, kan gestel word dat geskiedenis dus twee fasette het naamlik eerstens die gebeure soos dit werklik in die verlede plaasgevind het. Dit kan die geskiedenis as werklikheid genoem word. 'n Historikus soos Van Jaarsveld het die vraag gestel of daar hoegenaamd nog 'n ander betekenis aan geskiedenis geheg kan word as slegs die geskiedenis as werklikheid (Van Jaarsveld 1959:1-11).

Die tweede faset kom na vore wanneer gepoog word om op wetenskaplike wyse die geskiedenis as werklikheid so noukeurig moontlik te rekonstrueer uit die bronne wat beskikbaar is en geraadpleeg kan word, om dit vir die hede toeganklik te maak. Dit word dan aangedui as geskiedenis as wetenskap.

Nie alles wat gebeur het en dus verlede-werklikheid is, is egter geskiedenis nie. Eers as daar mense by betrokke is, is daar sprake van geskiedenis. Terselfdertyd is dit ook so dat nie alles wat in die verlede met die mens gebeur het of waarby die mens betrokke was, net daarom as geskiedenis beskryf kan word nie. Eers wanneer daar 'n verhouding en 'n verband kom tussen wat in die verlede met mense gebeur het of ge- 
beure waarby mense betrokke was en die huidige mense, kan daar van geskiedenis sprake wees. Om dit ietwat anders te stel kan gesê word dat geskiedenis daar is waar '... ' $n$ verband tussen die hede en die verlede in die gees en verstand van die mens van die hede bestaan' (Pont 1957:3).

Die twee fasette van geskiedenis kan so samgevat word (Botha 1980:4-5): 'Geskiedenis as werklikheid is die verlede soos dit onafhanklik van 'n ondersoeker voor God in werklikheid afgespeel het ...' (Van Jaarsveld 1977:2). (1) By geskiedenis as werklikheid gaan dit daarom om gebeure wat in 'n bepaalde tyd op 'n bepaalde plek plaasgevind het en waarby mense, individue en gemeenskappe betrokke was, en wat nou nog op een of ander wyse met die hede in verband staan en vir die huidige geslag iets te sê het. Die geskiedenis as werklikheid kan ook beskryf word as die afgespeelde gebeure wat weer onderverdeel kan word in selfdeurleefde of jongste geskiedenis, nog lewende geskiedenis of nabye verlede, en laastens ver verwyderde geskiedenis of verre verlede. Kortom, dit gaan om die verlede wat afgelope, onherhaalbaar en eenmalig verby is. Dit was en is wel daar, maar die verhaal wat daarvan getuig bestaan slegs in die bronne soos geskrewe stukke en dokumente, letterkundige bronne, monumente, argeologiese bronne ensomeer (Van Jaarsveld 1959:1-11; Van Jaarsveld 1976:1-3; Pont sj:47). (2) By geskiedenis as wetenskap gaan dit om die navorsing, bestudering en beskrywing van die geskiedenis as werklikheid soos wat dit in die bronne teenwoordig is. Dit gaan om 'n kritiese verhaal soos deur 'n historikus vertel word (Van Jaarsveld 1977:2). Dit is eintlik niks anders nie as 'n agterna-teenwoordig-maak of ook 'n poging tot rekonstruksie van die gekiedenis as werklikheid.

Alles wat tot dusver oor geskiedenis gesê is, is net so van toepassing op kerkgeskiedenis. Onmiddellik moet dan in gedagte gehou word dat die lid kerk in die samestelling van die begrip, 'n eie bepaalde karakter aan die lid geskiedenis gee. Soveel te meer is dit die geval as die kerk primêr gesien word as 'n geestelike gemeenskap en nie soseer as 'n ruimtelike grootheid nie (Steenkamp 1992:276). So het Pont dit reeds met sy intreerede oor kerkgeskiedenis gesê:

Dit is dus geskiedenis met ' $n$ reeds bepaalde grens, maar daarby kom dat die begrip Christendom nie soseer ruimtelik bepaalbaar is nie as wel in die eerste plek inhoudelik. En inhoudelik beteken Christendom daardie gemeenskap, daardie besondere groep mense in die hede en die verlede wat om Jesus Chritus, die eenmaal op aarde verskene Seun van God, geskaar is en wat Hom as Hoof en Heer glo en aanvaar.

(Pont 1957:5) 
Hoewel Pont hier nog die term Christendom gebruik het en nie die begrip kerk nie, het hy onder Christendom niks anders as die kerk verstaan nie. Dit blyk sondermeer as die sinne wat direk op die voorafgaande aanhaling volg, ook aangehaal word: 'Christendom, dit is dié gemeenskap waarvan Jesus Christus die stigter en die inhoud is. Vir die Christendom, of sal ek sê vir die Kerk (my beklemtoning: $\mathrm{S} J$ Botha) is Jesus Christus veel meer as 'n historiese figuur in die verlede, ....' (Pont 1957:5). Dat dit sy oortuiging was dat van Kerkgeskiedenis eerder as van Geskiedenis van die Christendom gepraat moet word, blyk ook as onder sy leiding die departement se naam in 1973 inderdaad verander is na Kerkgeskiedenis (Steenkamp 1992:276). Terloops kan die opmerking tog gemaak word dat hoewel die amptelike benaming Geskiedenis van die Christendom was, onder studente en dosente in die algemene spraakgebruik die term Kerkgeskiedenis gebruik is. In elk geval is met die term Kerkgeskiedenis aangesluit by 'n wye kring wat die mening toegedaan is dat die verskil tussen Kerkgeskiedenis en Geskiedenis van die Christendom 'n wesenlike verskil is en dat Kerkgeskiedenis die korrekte benaming is (Eybers-König-Stoop 1973:8486). Die kerk kan ook omskryf word as die liggaam van Christus, dit is 'n gemeenskap van gelowiges of 'n heilige vergadering van almal wat waarlik in Christus glo, wat almal hulle volle saligheid in Jesus Christus verwag en in sy bloed gewas is, geheilig en verseël deur die Heilige Gees (Ned Geloofsbelydenis art 27). Maar terselfdertyd is die kerk ó́k 'n werklike fisiese gemeenskap van mense wat in die wêreld leef en werk en as sodanig 'n verlede het. As gemeenskap wat rondom Woord en Sakramente geordend bestaan, is die kerk aanwysbaar in die wêreld en het ook ' $n$ geskiedenis wat nagevors en beskryf kan word. Die kerkgeskiedenis as wetenskap wat die geskiedenis van die kerk moet navors en beskrywe moet met beide hierdie fasette van die kerk rekening hou. In die eerste plek moet onthou word dat dit in die kerkgeskiedenis gaan om die geskiedenis van daardie liggaam waarvan Jesus Christus die Hoof en Heer is. So gesien 'is die kerkgeskiedenis óok die geskiedenis van wat Jesus Christus in die wêreld doen - direk deur sy Woord en Gees en indirek deur die gelowiges' (Pont s a:37). Hier maan Pont dat daaruit nie afgelei mag word enersyds dat kerkgeskiedenis openbaringsgeskiedenis is nie, of andersyds dat God nie in die geskiedenis besig is nie.

Wat baie goed vasgehou moet word is dat in en met Jesus Christus die koninkryk van God na die mens toe gekom het, maar ook dat die koninkryk van God in sy volheid nog moet kom. Met die wederkoms van Jesus Christus sal dit gebeur. Die tyd tussen die koms en die wederkoms is dan die tyd van die kerkgeskiedenis wat ' $n$ reglynige baan het tussen die twee punte. Daaroor stel Pont ( $\mathrm{s}$ a:38): 'Die kerkgeskiedenis tussen die twee punte is dus die geskiedenis van Jesus Chritus én die Heilige Gees wat direk en indirek in kerk en wêreld besig is. 'Hierdie besig wees van Jesus Christus is egter alleen deur die geloof herkenbaar. Daarom moet gesê word dat die kerkgeskiedenis alleen in sy bedekte, verborge vorm 'n geskiedenis van Jesus Christus is. In die 
navorsing en optekening van die vereledegebeure van die kerk, moet die kerkhistorikus dus bewus wees van 'n vertikale lyn en nie maar net op die horisontale lyn konsentreer nie.

As die kerkgeskiedenis as wetenskap wil voldoen aan die vereistes wat aan die geesteswetenskappe gestel word (vgl hier Dreyer 1974:119-159), sal net soos by die algemene geskiedenis die historiese metode toegepas moet word. Dit kom daarop neer dat aan kerkgeskiedenis 'n dubbele verantwoordelikheid opgelê word: 'n verantwoordelikheid teenoor sowel die teologie as die geskiedeniswetenskap. Hoewel dit nie sonder spanning en probleme is nie, durf dit nie vermy word nie (Pont s a:48). By die toepassing van die historiese metode is daar drie fases wat voor oë gehou moet word, naamlik die gebondenheid aan die bronne, die vooroordele en maatstawwe van die kerkhistorikus en laastens die besondere aard van die kerk as die liggaam van Christus in die wêreld (Pont s a:47-50).

Juis op hierdie punt is dit waar die historikus en dus ook die kerkhistorikus betrokke moet wees om sy taak en opdrag te kan uitvoer. Dit is immers hier waar die kerkgeskiedenis as wetenskap gestalte begin kry. Die kerkhistorikus het die opdrag om via die bronne wat oor die kerkgeskiedenis as werklikheid getuig, homself te verplaas na daardie tyd en plek waar die kerkgeskiedenis as werklikheid afgespeel het om dit van binne te belewe en dit dan so getrou en eerlik moontlik vir die hede en die lewende mens toeganklik te maak. Die doel daarvan is om 'n lewende verband en verhouding tussen die afgelope kerkgeskiedenis as werklikheid en die lidmate en kerk van die huidige oomblik tot stand te bring. Op die wyse is die geskiedenis as werklikheid dan nie dood en verby nie, maar word dit lewend in die hede en kan daar dan as't ware 'n gesprek plaasvind tussen die verlede en die hede of kan 'n reeds bestaande gesprek verder gestimuleer word. So kan kerkgeskiedenis dan die waarde, betekenis en doel kry wat, soos prof Pont in sy intreerede betoog, deur die Bybel daaraan geheg word (Pont 1957:3-4).

\section{BETEKENIS}

By die nadenke oor die begrip betekenis moet die begrip sin ook ter sprake gebring word en die vraag oorweeg word of sin hier as wisselvorm vir betekenis gebruik sou kon word. Hoewel daar intrinsiek geen verskil bestaan tussen die twee terme nie, is dit tog moontlik om die terme verskillend maar aanvullend tot mekaar te gebruik. Dit doen professor P S Dreyer as hy cor die probleem van die sin van die geskiedenis handel. In sy beredenering van die probleem gebruik hy ter wille van die duidelikheid die term $\sin$ in verband met die totaliteit van die geskiedenis en die term betekenis waar daar sprake is van 'n onderdeel van die geskiedenis. Hy toon dan aan dat die betekenis, indien so gebruik, altyd in dubbele opsig ondergeskik is aan die sin. In die eerste. 
plek word die betekenis dan medebepaal deur die sin, maar nie omgekeerd nie. Dit wil sê dat geskiedenis nie eers sin kry omdat daar betekenis aan bepaalde gebeurtenisse geheg word nie (Dreyer 1974:219-220). Tweedens blyk die ondergeskiktheid van betekenis aan sin wanneer geskiedenisbeskouings wat geen sin in die geskiedenis sien nie, nagegaan word. 'n Bepaalde gebeurtenis kan op baie terreine gevolge hê, maar as daaraan geen finale of universele betekenis met eskatologiese implikasies toegeken word nie verloor dit sy krag (Dreyer 1974:220).

Berkhof (1958:13) wys daarop dat die sin van die geskiedenis op drieërlei wyse verstaan kan word. Eerstens kan gekiedenis gesien word as die veld van die menslike dade en beslissings, as terrein waar die mens sy kultuuropdrag realiseer of waar hy homself verwerklik. Tweedens kan dit dui op die wyse waarop die mensegebeure met God in verband staan, dit wil sê hoe Hy dit in sy hand hou en mense en dinge gebruik. Derdens kan dit verstaan word in 'n betekenis wat die eerste twee insluit maar tog verder gaan naamlik as doel. In sy boek Christus de zin der Geschiedenis kies hy vir die derde moontlikheid en dan spreek die titel van die boek wel vir homself. Hiervolgens het die mensegebeure deur die eeue 'n bepaalde rigting, dit is soos 'n stroom wat êrens heen beweeg.

Van Jaarsveld oordeel dat die vraag na die sin van die geskiedenis betrekking het op die orsprong, eenheid, rigting en doel van die historiese verloop (Van Jaarsveld 1977:42). Ook Dreyer stel dat die geskiedenis alleen sinvol kan wees as die einde van die geskiedenis '...'n nagestreefde doel as hoogste waarde is' (Dreyer 1974:218). Hy stel dan vyf voorwaardes waaraan die einde moet voldoen: dit moet in die volle sin van die woord eschaton en telos wees, dit moet iets goeds en menswaardigs wees, dit moet die bereiking van 'n hoogste en laaste doel wees, menslike doen en late moet meewerk aan die bereiking al dan nie van die einde en dit kan net 'n ware eschaton wees as die hele mensdom dit bereik.

Vir die historikus is die probleem van die sin van die geskiedenis van baie groot belang. Omdat die sinsprobleem te make het met die sinvolheid van die menslike bestaan en die mens wesenlik historiese wese is, vereis die probleem van die sin van die geskiedenis besinning (Dreyer 1974:26). Dit is egter 'n probleem waarteenoor baie historici skepties en afwysend staan. Waar hulle nog die synsprobleem en die kenprobleem as deel van hulle wetenskaplike problematiek aanvaar, is hulle van mening dat geen historikus van naam hom met iets besig mag hou wat niks anders as 'n onwetenskaplike, metafisiese spekulasie is nie. Dikwels word dit verwys na die filosowe en teoloë, en dan nie sonder 'n mate van spot nie, as 'n probleem wat op hulle vakterrein lê en deur hulle filosofering en teologisering van 'n antwoord voorsien moet word. 'n Historikus soos Van Jaarsveld stel dit so: 
Terwyl die nog lewende verlede die terrein is van veral die wetenskaplike historici, die verwyderde verlede dié van vakspesialiste en die selfdeurleefde verlede (dié) van die politici en die pseudo-historici, is die historiese werklikheid in sy totaliteit die terrein van die teoloë en die filosowe.

(Van Jaarsveld 1977:42)

Dit is 'n feit dat sedert die opkoms van die historisme, historici oor die algemeen skepties begin staan het teenoor die vraag na die sin van die geskiedenis. Die strenger beskouing van die grense, moontlikhede en eise van wetenskaplike historiese navorsing en geskiedskrywing, of anders gestel: groter begrip vir die kenteorie van die geskiedenis, lê ten grondslag van hierdie skeptiese en afwysende houding (Dreyer 1974:232).

Die historici se dilemma kan begryp word as dit bedink word dat wanneer oor die sin van die geskiedenis gehandel moet word, nie alleen die verlede nie, maar ook die toekoms in berekening gebring moet word. Want wanneer oor die sin van die geskiedenis gepraat word, vind daar ' $n$ verskuiwing in die betekenis van die term geskiedenis plaas, omdat dan nie alleen die verlede in totaliteit nie, maar ook die toekoms in totaliteit geïmpliseer word (Dreyer 1974:217). Daarom stel Dreyer (1974:218): "Van die sin van die geskiedenis kan alleen gepraat word wanneer die geskiedenis van die begin tot die einde oorsien kan word en die einde 'n nagestreefde doel as hoogste waarde is'.

Wie dus oor die sin van die geskiedenis 'n gesagvolle uitspraak wil maak, moet kennis kan verwerf oor die totaliteit van gebeure vanaf die absolute begin tot by die finale einde. Om tot kennis van die toekoms te kom, is nie deur historiese navorsing ontdekbaar en vasstelbaar nie. Dit het tot gevolg dat die sin van die geskiedenis ook nie langs die weg van die historiese navorsing ontdek of vasgestel kan word nie. Dit is inderdaad prinsipieel onmoontlik, soos Dreyer ook aantoon. Drie redes kan aangevoer word (Dreyer 1974:230-231):

Die eerste rede is te wyte aan die reeds genoemde feit dat die toekoms nie die voorwerp van wetenskaplike navorsing kan wees nie, allermins van historiese navorsing. Die tweede rede is geleë in die feit dat nie net die toekoms nie, maar ook '... die oorsprong as sinvolle begin ...' nie voorwerp van wetenskaplike navorsing kan wees nie. Derdens is dit nie die taak van die geskiedenis as wetenskap om enige eschaton as hoogste waarde voor te skryf wat nagestreef moet word nie. Die feit dat die ge- 
skiedenis as wetenskap nie die vraag na die sin van die geskiedenis deur historiese navorsing kan vasstel nie, het meegebring dat vanuit metahistoriese gesigspunte na 'n antwoord gesoek is.

Van Jaarsveld vat die gesigspunte kortliks so saam:

Aan die begin het die Westerse mens hom vir 'n verklaring van die geskiedenis aan die Bybelse geopenbaarde waarheid gehou maar al gaandeweg is die goddelike Voorsienigheid vervang deur immanente of binnehistoriese gesigspunte ('ismes') wat bv uitgaan van die menslike verstand (rasionalisme en positivisme), die hart (romantiek), die maag (materialisme en Marxisme) en sy voortplanting (naturalisme, biologisme en Naziïsme). Hoe verder hy van die Bybel af weg beweeg het, hoe onsekerder het sy verklarings geword. Op die duur het dit oorgegaan in die ontkenning van ' $n$ sin van die geskiedenis (nihilisme).

(Van Jaarsveld 1977:42)

Al die pogings kan in twee hoofgroepe verdeel word naamlik die een '... groep wat die verloop van die geskiedenis as eenlynige voortgang sien (die teosentriese en die vooruitgangsopvatting) en 'n groep wat die verloop as 'n sirkelgang beskou (die sikliese opvatting)' (Van Jaarsveld 1977:42). Hierdie genoemde groepe het groot invloed uitgeoefen op die historiese denke en op die geskiedskrywing en daarom moet die historikus en dus ook die kerkhistorikus, hom hiervan rekenskap gee (Dreyer 1974:26).

Uiteraard kan hierdie sisteme nie in 'n enkele lesing nagegaan en bespreek word nie. Daar bestaan wel werke waarin uitvoerig oor elke noemenswaardige beskouing gehandel word (vgl Louwith 1949; Berkhof 1958; Geyl 1958; Van Jaarsveld 1980; Wilburn 1966; Van't Spijker 1977). Dreyer verwys na hierdie sisteme as kwasi-wetenskaplike metafisiese sisteme wat in wese niks anders is as uitdrukking van die lewensopvatting van die ontwerper daarvan nie (Dreyer 1974:241-242). Dit bring twee verdere vrae na vore: Beteken dit dat die geskiedenis geen sin het nie? en: Is elke poging om die sin van die geskiedenis aan te dui dan waardeloos? Om die sinloosheid van die geskiedenis aan te toon is ook 'n totaalvisie nodig en dit val net so goed buite die moontlikheid van wetenskaplike historiese navorsing. Tweedens is die vraag na die sin van die geskiedenis wel waardevol en selfs noodsaaklik, mits in gedagte gehou word dat dit waarde en betenis vind in ander gronde as historiese navorsing (Dreyer 1974: 233). Dreyer (1974:240) toon aan dat die historikus noodwendig 'n metahistoriese fondament nodig het waarop hy die gebou van sy geskiedskrywing kan oprig. Terselfder- 
tyd beskou hy die antimetafisiese houding van die historici as oorsaak daarvan dat die geskiedskrywing van vandag dikwels so 'n bloedarmoedige indruk maak (1974:239). Sonder dat die eise van die geskiedenis as wetenskap in die minste prysgegee hoef te word, moet die historikus tog 'n bepaalde oortuiging hê waarmee hy die historiese werklikheid benader. Dit is onontkombaar omdat die betekenis van geskiedenis nie primêr in die geskiedenis as wetenskap lê nie, maar dat dit ontsaglike betekenis ten opsigte van die mens se eksistensiële plekbepaling het. Al kan die geskiedenis as wetenskap nie die vraag na die sin van die geskiedenis beantwoord nie, hoef dit nie te beteken dat die historikus 'n skeptiese of agnostiese houding ten opsigte van die metahistoriese moet inneem nie. Dit hoef ook nie te beteken dat die Christelike geskiedsbeskouing as onwetenskaplik of as wetenskaplik onbewysbaar verwerp moet word nie (Dreyer 1974:241). Dit laat Dreyer kies vir die Christelike geskiedenisbeskouing teenoor die ander kwasi-wetenskaplike metafisiese sisteme om 'n antwoord te gee op die vraag na die sin van die geskiedenis. Hy argumenteer verder so:

Die aanvaarding van die Christelike geloof as basis waarvandaan mens die geskiedenis benader, is nie 'n wetenskaplike saak nie, maar 'n saak van persoonlike beslissing. Wat egter wel 'n saak van wetenskaplike kritiek is, is die vraag of die gekose basis van interpretasie reg laat geskied aan die voorwerp van historiese studie, of dit kan klop met die aard van die geskiedenis-as-wetenskap en of dit 'n oplossing bied vir die probleme van metahistoriese aard waarvoor die geskiedenis-as-wetenskap homself gestel vind. Hierdie kritiese toets kan die Christelike geloof beter deurstaan as die metafisiese sisteme, eenvoudig omdat die Christelike geloof meegewerk het aan die vorming en ontwikkeling van die geskiedenis-as-wetenskap in die Weste en omdat die Christelike geloof geen metafisiese stelsel is nie.

(Dreyer 1974:242-243)

Eers in die Christelike geskiedenisbeskouing is daar sprake van 'n totale beskouing '... waarin die geskiedenis as ' $n$ geheel (beide in die betekenis van tyd as geheel en die mensheid as eenheid) sin het en waarin elke gebeurtenis en mens in sy doen en late betekenis kry' (Dreyer 1974:225). As konklusie na sy besinning oor die Christelike sin van die geskiedenis stel Dreyer dan: 'die Christelike sin van die geskiedenis berus per slot van rekening op geloof - op die verhouding tussen die historikus en God' (Dreyer 1974:251). 
In die Christelike beskouing lê die sin van die geskiedenis opgesluit in die koms en die wederkoms van Jesus Christus. Sy koms is die singewende middelpunt omdat dit wesenlik betrokke is op sy wederkoms wat die einde van die geskiedenis is. Dat hy gekom het en sy heilswerk in die geskiedenis volbring het, is van beslissende betekenis vir die hele geskiedenis van die hele mensheid. Terselfdertyd was dit die grondslag en die voorbereiding van die einde. Die wederkoms as voleindiging van die heilsgebeure, is tegelyk deel van die heilsgebeure en die einde van die geskiedenis (vgl Cullman 1971). Dit is duidelik dat vir die Christelike geskiedenisbeskouing God 'n eindpunt bepaal het en dat Hy die hele geskiedenis lei om daarop af te stuur en dat dit daarom 'n besliste doel het. Hierdie eenlynige beweging vanaf 'n bepaalde begin na 'n bepaalde einde toe, hou in dat, al sou gebeurtenisse soortgelyk van aard telkens te voorskyn tree, daar geen herhaling kan wees nie (Dreyer 1974:225).

As die geskiedenis sy sin ontleen aan die koms en die wederkoms van Jesus Christus, kan die kerkgeskiedenis nêrens anders sin vind nie. Dit het ook die basis van Pont se argumentvoering in sy intreerede gevorm en oor die jare het hy dit ook nader uitgewerk. In sy intreerede het hy gestel dat Jesus Christus vir die kerk die betekenis het dat God, die Ewige, Hom geopenbaar het deur in die geskiedenis in te daal. Vir die kerk is hierdie indaling van God vir die geskiedenis van fundamentele en omvattende belang en betekenis. Alleen omdat Jesus Christus, dit is God, in die geskiedenis ingetree het, is geskiedenis moontlik. Die koms en die heilswerk van Jesus Christus vorm die singewende middelpunt van die geskiedenis, met sy wederkoms as die finale eindpunt van die geskiedenis. Jesus Christus is daarom die verklarende sin van alle geskiedenis (Pont 1957:5-7). Die taak van die kerk soos Pont dit gesien het was om die Woord van God, dit is Jesus Christus, in gehoorsaamheid te dien. Dan stel hy verder:

En die Kerk dien die Woord van God deurdat sy haar tydgenote oproep tot die ontmoeting met die verlede, meer nog tot die ontmoeting met Jesus Christus, die middelpunt van die geskiedenis, opdat die kerk en diegene wat deur haar aangespreek word met dankbaarheid, met vreugde en in vaste geloof die toekoms, Jesus Christus tegemoet kan gaan.

(Pont 1957:8)

Dat Jesus Christus die dragende en singewende middelpunt van die kerkgeskiedenis as totaliteit is, het die konsekwensie dat die betekenis van elke onderdeel van die kerkgeskiedenis daardeur medebepaal word. Daarmee moet die kerkhistorikus in sy wetenskapsbeoefening rekening hou. Natuurlik kan hy die sinvolheid van kerkgeskiedenis 
nie deur die historiese metode wetenskaplik navors en vasstel nie. Dit is iets wat van buite gekom het en wat hy deur 'n persoonlike beslissing tot sy eie gemaak het. Dit is ook duidelik dat die sin van die kerkgeskiedenis nooit kan verander nie. Vir die Christengelowige van alle tye is dit dieselfde vaste gegewene.

Die vraag of sin en betekenis in die titel van die voordrag omruilbaar gebruik kan word, kan daarom so beantwoord word: as die bedoeling van die term kerkgeskiedenis is dat die kerkgeskiedenis in sy totaliteit, vanaf die begin tot by die einde $=$ die wederkoms) aan die orde is, dan sou sin wel gebruik kon word. Dit is moontlik om dit so te verstaan. Dit is egter ook moontlik om kerkgeskiedenis slegs as die gebeure van die verlede te verstaan, hetsy as of die selfdeurleefde geskiedenis, of die geskiedenis van die nabye verlede of die geskiedenis van die verre verlede, of slegs as onderafdeling van een van die drie. Dan sal betekenis meer gepas wees, mits daarby in gedagte gehou word dat die sin van die kerkgeskiedenis soos hierbo beredeneer, vir die betekenis medebepalend is.

Daar kan nie anders as om beide terme, sin en betekenis aan die kerkgeskiedenis te verbind wanneer dit aan die geslag van vandag gekommunikeer moet word nie. Dit bring weer die taak van die kerkhistorikus ter sprake. As bemiddelaar wat die gesprek tussen die verlede en die hede aan die gang moet kry en voortdurend moet stimuleer, kan hy nie anders as om die sin van die kerkgeskiedenis ter sprake te bring nie. Dit kan seker veronderstel word dat 'n kerkhistorikus minstens 'n Christengelowige sal wees en verkieslik ook nog teoloog en dienaar van die Woord. Dit is immers die vereistes ten opsigte van die leerstoel in kerkgeskiedenis aan hierdie fakulteit. As Chritengelowige, wat in 'n bepaalde verhouding tot God staan, kan hy nie anders as om vanuit die Christelike (kerk)geskiedenisbeskouing die historiese werklikheid te benader nie. Dit hoef hoegenaamd geen onaanvaarbare subjektiwisme in die beoefenig van sy vakgebied tot gevolg te hê nie, maar wel wat Dreyer (1974:239) 'n noodsaaklike en onvermydelike subjektiwiteit noem. Dit hou duidelik in dat die kerkhistorikus hom voortdurend sal verantwoord oor sy eie voorveronderstellings en dat hy nie in die strik sal trap waarvan Herbert Butterfield praat nie: 'Amongst historians, as in other fields, the blindest of all the blind are those who are unable to examine their own presuppositions and blithely imagine therefore that they do not possess any' (Butterfield 1954:46).

As wetenskaplike sal die kerkhistorikus by sy navorsing van die gebeure van die verlede, dit is die kerkgeskiedenis as werklikheid, en by die optekening daarvan, aan alle voorwaardes van die kerkgeskiedenis as wetenskap moet voldoen. Hy sal so sorgvuldig moontlik, met eerlikheid en integriteit, die waarheid van die kerkgeskiedenis as werklikheid moet vasstel en die hede daarmee konfronteer. Hoewel reeds 'n eeu gelede gesê, is ' $n$ woord van Acquoy steeds relevant: 
... dat het doel der kerkgeschiedvorsching geen ander mag zijn, dan het zoeken naar zuivere kennis van hetgeen op christelijk gebied heeft plaats gehad. Doch tevens ligt het voor de hand, dat dit zoeken op zich zelf weinig zou baten, wanneer er niet een verder strekkend doel, namelijk het te boek stellen van het gevondene, aan werd verbonden.

(Acquoy 1910:5-6)

Uiteraard is dit nie moontlik vir 'n enkeling kerkhistorikus om die totaliteit van die kerkgeskiedenis as werklikheid, dit wil sê alles wat van die begin af tot op vandag gebeur het, in elke afsonderlike onderdeel na te vors en te ken nie. Daar sal dus noodwendig 'n seleksie gemaak moet word van die onderdele wat as relevant vir die hede beskou kan word. Omdat ' $n$ keuse gemaak word sal na die betekenis van elke onderdeel gevra moet word en die kerkhistorikus sal voortdurend in gedagte moet hou dat elke onderdeel se betekenis deur die sin van die kergeskiedenis medebepaal word.

\section{VANDAG}

Die vraag moet nou gestel word of die hede, die huidige geslag enigsins kennis hoef te neem van die verlede. Is dit werklik noodsaaklik vir die hede om met die verlede in gesprek te tree en sorgvuldig te luister na die verlede? Dreyer bied hierop ' $n$ voldoende antwoord as hy sê:

Die Christelike visie word verder gekenmerk deur die feit dat die historiese lyn nie net bepaal word deur die verlede nie, maar ook deur die toekoms, deur die doel wat voorlê en waarheen die hele geskiedenis beweeg. Om hierdie rede word die hede tot 'n byna skrikwekkende mate gelaai met betekenis: die hede is die punt waardeur die die verlede na die toekoms loop; die doen en late van elke mens, gemeenskap, volk, staat, ens werk mee aan die bespoediging of vertraging van die koms van die einddoel, die koninkryk van God (my beklemtoning-SJB). Die hede het dus beslissende betekenis en elke persoon dra die verantwoordelikheid vir die beslissing - en daarmee saam ook die skuld.

(Dreyer 1974:225)

Dit lê presies in lyn met Pont se betoog in sy intreerede waar hy konkludeer '... dat die verlede ' $n$ steeds toenemende verantwoordelikheid op die skouers van die teenwoordige 
geslag plaas' (Pont 1957:4). Daar kan geen twyfel bestaan dat die hede die gebeurtenisse van gister, dit is die verlede, moet ken nie. Dit is nie alleen tot sy eie nadeel en skade as die hede die geskiedenis as werklikheid en die bestudering daarvan verwaarloos nie, dit getuig selfs van ondankbaarheid en ongehoorsaamheid teenoor God. Dit is daarom die verantwoordelikheid van die hede om sorgvuldig te luister na die verlede voordat hy self iets sê. Die hede as môre se verlede sal dit nie kan vermy om self iets na te laat nie, en sy eie verlede verswaar sy verantwoordelikheid ten opsigte van wat hy nalaat. Dit is tog ook belangrik om kortliks die aandag te bepaal by die hede as gespreksgenoot in die gesprek met die verlede. Hoe lyk die hede? Dit is mode om na die hede as post-modern te verwys. Word egter gevra na wat postmodernisme is, blyk die uitdrukking 'soveel hoofde soveel sinne' baie waar te wees. In 'n redelik onlangse artikel wys Loubser (1997:49) daarop '.. dat daar baie soorte postmodernisme is, wisselend van aggressiewe, missionêre, sagte, tot hoë en lae postmodernisme'. Volledig kan daar nie en hoef daar ook nie by hierdie geleentheid op die vraag na wat postmodernisme is, ingegaan te word nie. Slegs enkele opmerkings, word gemaak. Loubser se kort beskrywing van modernisme is hier dienlik:

Modernisme is ' $n$ baie algemene term om die kultuurfase van die Westerse wêreld te beskryf wat tot ongeveer die sestigerjare dominant was. Hierdie fase word onder andere gesimboliseer deur Newton se fisika, La Place se clockwork universe, en Kant en Hegel se filosofie. Die beheersende motief van die modernisme is die vertroue in die objektiwiteit van die menslike rede. Dit gaan uit van 'n vertroue in die vermoë in die rede om ' $n$ samehangende beeld van die werklikheid te kan vorm en dit te kan beheer. Danksy die moderne tegnologie wat hierdie vertroue in die rede help skep het, is atoomkrag uitgevind, mense na die maan gestuur en die aangesig van die planeet verander.

(Loubser 1997:45)

Op die terrein van die geloof en teologie het die modernisme 'n Gods- en geloofsverduistering as resultaat opgelewer. Vanweë die almag van die menslike rede, is óf nie meer na die stem van God geluister nie of sy spreke is so gerelativeer dat dit niksseggend geword het. Die woord postmodernisme impliseer baie duidelik dat die hede die modernisme agter hom het. As gestel word dat die postmodernisme op sy beurt 'n vertrouenskrisis in die almag van die menslike rede teweeg gebring het en dat tans selfs oor geloof gepraat kan word op 'n wyse wat nie in die tyd van die modernisme moontlik was nie (Loubser 1997:48), beteken dit nie dat geloof tans vanselfsprekend as iets sinvols verwelkom word nie. Spreke oor geloof word slegs geakkommodeer as deel 
van die postmoderne allegaartjie. Slegs deur enkele begrippe waarmee Loubser die negatiewe gevolge van die postmodernisme beskryf, uit te lig, bring die besef dat die postmoderne era net soveel probleme en gevare vir geloof, kerk en teologie inhou as wat die geval onder die modernisme was. Hy praat van sulke sake soos dat dit mense ernstige sinsverlies laat ervaar wat hulle in psigotiese depressie dompel, dat daar nie meer sprake is van koherensie nie maar eerder van radikale relatiwisme. Hierby voeg hy dan nog: "Die drie "doodsondes" van die postmodernisme is: beperkinge op die vryheid van die enkeling, die aanspraak op finale objektiwiteit en rassisme. Sy drie "hemelse deugde" word uitgedruk met die slagwoorde "deursigtigheid", "netwerk" en "empowerment"' (Loubser 1997:48-49).

Uit die enkele opmerkings oor postmodernisme kan wel gekonkludeer word dat op elke terrein van die kerklike lewe gehoorsamer aan God en noukeuriger as ooit gewerk sal moet word om die huidige geslag weerbaar te maak in hierdie hede. Die kerkgeskiedenis as wetenskap sal onverpoosd moet voortgaan om die hede met die verlede in gesprek te bring en in gesprek te hou vanuit die vaste geloofsoortuiging dat die kerkgeskiedenis sin het en elke onderafdeling betekenis.

\section{Literatuurverwysings}

Acquoy, J G R 1980. Handleiding tot de Kerkgeschiedschrijving en de Kerkgeschiedvorsching. Tweede Druk. 'S Gravenhage: Martinus Nijhoff.

Berkhof, H 1950. Geschiedenis der Kerk. G F Callenbach: Nijkerk.

Botha, S J 1980. Kerkgeskiedenis in die konteks van die Hervormde Teologiese Opleiding aan die Universiteit van die Noorde. Universiteit van die Noorde. (Reeks C 56.)

Butterfield, H 1954. Christianity and History. London: Camelot Press.

Cullmann, O 1971. Christ and time. London: SCM Press.

Dreyer, P S 1974. Inleiding tot die filosofie van die geskiedenis. Kaapstad-Pretoria: HAUM.

Geyl, P 1958. Geschiedenis als medespeler. Utrecht-Antwerpen: Aula Boeken.

Jedin, H 1963. Handbuch der Kirchenheshichte, Band 1. Freiburg-Basel-Wien: Herder.

Loubser, J A 1997. Maak geloof nog sin? Die postmoderne moontlikheid van on/geloof. Tydskrif vir Geesteswetenskappe 37/1, 44-56.

Louwith, K 1949. Meaning in history. Chicago: University of Chicago Press.

Pont, A D 1963. Enkele opmerkings oor objektiewe kerkgeskiedskrywing in HTS 18/4, 146-153.

1991. Kerkgeskiedenis. Pretoria:Kital 
Pont, A D s a. Inleiding tot die geskiedenis van die kerkgeskiedenis. Universiteit van Pretoria: Studiehandleiding.

Pont, A D(1957). Die geskiedenis van die Christendom. HTS 13/1, 2-8.

Selge, K-V 1982. Einführung in das Studium der Kirchengeschichte. Darmstadt: Wissenschftliche Buchgesellschaft.

Van 't Spijker, W 1977. Reformatie en geschiedenis. Goes: Oosterbaan en Le Cointre BV.

Van Jaarsveld, F A 1959. Die Afrikaner en sy geskiedenis. Kaapstad: Afrikaanse persboekhandel.

1961. Lewende verlede. Johannesburg: Afrikaanse Pers-boekhandel.

Van Jaarsveld, F A 1976. Probleme by die onderrig van geskiedenis. Pretoria: Van Schaik.

1980. Westerse historiografie en geskiedenisfilosofie. Pretoria: HAUM.

Van Jaarsveld, F A en Rademeyer, J I 1977. Teorie en metodiek vir geskiedenisonderrig. Johannesburg:Perskor.

Wilburn, R G 1964. The historical shape of faith. Philadelphia: The Westminister Press. 